\title{
CMV Colitis in Immunocompetent Patients-A Case Series
}

\author{
Anushka Verma ${ }^{1}$ Muppa Indrakeela Girish ${ }^{2}$ Amol S. Dahale ${ }^{2}$ Ashok Dalal ${ }^{3}$ Sanjeev Sachdeva ${ }^{3}$
}

${ }^{1}$ Department of Physiology, Lady Hardinge Medical College, New Delhi, India

2 Department of Gastroenterology and Hepatology, DY Patil Medical College, Pune, Maharashtra, India

${ }^{3}$ Department of Gastroenterology and Hepatology, Govind Ballabh Pant Institute of Postgraduate Medical Education and Research, New Delhi, India

J Digest Endosc 2021;12:245-246.

Cytomegalovirus (CMV) colitis is a common occurrence in immunocompromised patients but uncommon in immunocompetent patients with usually mild and self-limiting symptoms and rarely gives rise to serious complications. ${ }^{1}$ Gastrointestinal involvement is very rare in immunocompetent individuals; however, the commonly involved sites are colon and rectum. ${ }^{2}$ We aimed to share our experience of CMV colitis in immunocompetent patients. We are sharing our experience of four patients having immunocompetent status. Our aim was to analyze clinicoepidemiological-associated attributes of CMV colitis in immunocompetent individuals. The average age of

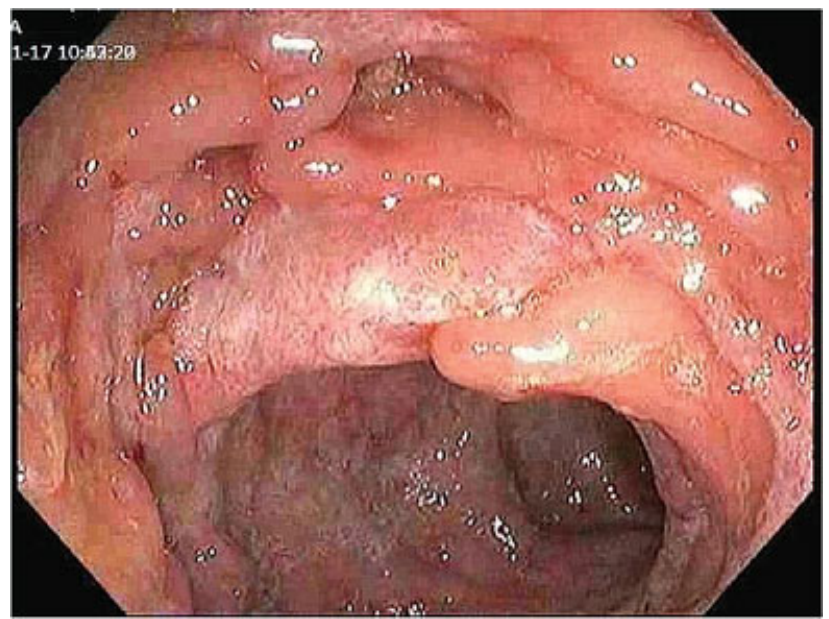

Fig. 1 Transverse colon showing multiple discrete deep ulcers.

DOI https://doi.org/ $10.1055 / \mathrm{s}-0041-1742134$ ISSN 0976-5042.
Address for correspondence Amol S. Dahale, MD, DM, Department of Gastroenterology and Hepatology, DY Patil Medical College, Pune, Maharashtra, India (e-mail: amolsd_1986@yahoo.com).

patients in the study was 53.5 years ( - Table 1 ). In the present study, no of patients were four in which two were females (50\%) and two were males (50\%). Frequently occurring symptoms were abdominal pain and diarrhea. Three patients presented with abdominal pain (75\%) and two patients with bloody diarrhea (50\%). Comorbidities seen in involved patients were diabetes in 2 (50\%) and hypertension and coronavirus disease 2019 in another (25\%); one patient did not have any comorbidities. Diabetes was controlled in two patients with antidiabetic treatment and hemoglobin A1c was under-control. The common organs involved were sigmoid and rectum. The common

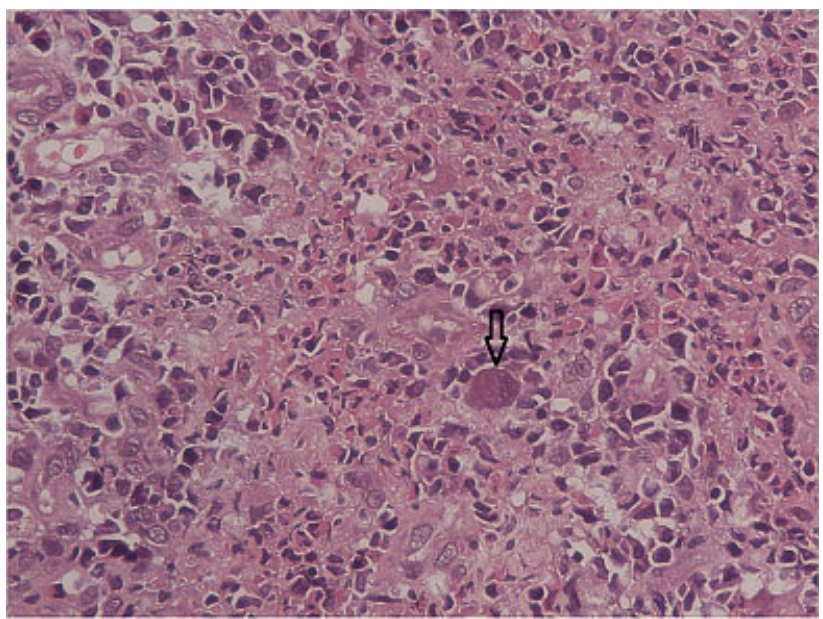

Fig. 2 Histopathological examination: Arrow showing cytomegalic cells containing basophilic intranuclear inclusion body.

(C) 2022. Society of Gastrointestinal Endoscopy of India. All rights reserved.

This is an open access article published by Thieme under the terms of the Creative Commons Attribution-NonDerivative-NonCommercial-License, permitting copying and reproduction so long as the original work is given appropriate credit. Contents may not be used for commercial purposes, or adapted, remixed, transformed or built upon. (https://creativecommons.org/ licenses/by-nc-nd/4.0/)

Thieme Medical and Scientific Publishers Pvt. Ltd., A-12, 2nd Floor, Sector 2, Noida-201301 UP, India 
Table 1 Clinical, colonoscopic features and outcome of cases

\begin{tabular}{|l|l|l|l|l|l|l|}
\hline Age/Sex & Comorbidity & Clinical features & Colon areas involved & Colon findings & Diagnosis & Outcome \\
\hline $65 / \mathrm{F}$ & Diabetes & $\begin{array}{l}\text { Pain abdomen, } \\
\text { diarrhea }\end{array}$ & $\begin{array}{l}\text { Transverse, ascending } \\
\text { colon, cecum }\end{array}$ & $\begin{array}{l}\text { Multiple, deep and } \\
\text { superficial ulcers }\end{array}$ & HPE + IHC & Cured \\
\hline $52 / \mathrm{F}$ & Nil & $\begin{array}{l}\text { Pain abdomen, } \\
\text { bloody diarrhea }\end{array}$ & Sigmoid & $\begin{array}{l}\text { Multiple, } \\
\text { superficial ulcers }\end{array}$ & HPE + IHC & Cured \\
\hline $45 / \mathrm{M}$ & Diabetes & $\begin{array}{l}\text { Pain abdomen, } \\
\text { bloody diarrhea }\end{array}$ & Rectum, rectosigmoid & $\begin{array}{l}\text { Multiple } \\
\text { superficial ulcers }\end{array}$ & HPE + IHC PCR+ & Cured \\
\hline $55 / \mathrm{M}$ & $\begin{array}{l}\text { Hypertension } \\
\text { COVID-19 }\end{array}$ & Diarrhea & Rectum & $\begin{array}{l}\text { Multiple, } \\
\text { deep ulcers }\end{array}$ & HPE + IHC & Death \\
\hline
\end{tabular}

Abbreviations: COVID-19, coronavirus disease 2019; HPE, histopathological examination; IHC, immunohistochemistry; PCR, polymerase chain reaction.

finding in colonoscopy was multiple superficial and deep ulcers (-Fig. 1). The diagnosis of CMV colitis within the four patients was on the basis of histopathology and immunohistochemistry. Tissue CMV polymerase chain reaction (qualitative) was performed in two patients' samples, and only one of them was positive. Histopathology reports of all four patients showed inclusion bodies with cytopathic effect, which was confirmed within immunohistochemistry (-Fig. 2). Three patients received treatment, and subsequently, their condition improved. However, one patient expired due to myocardial infarction before receiving the treatment. CMV colitis is very uncommon in immunocompetent patients and should be considered with appropriate clinical intervention to achieve positive outcome from the treatment.
Conflict of Interest

None.

\section{References}

1 Dinesh BV, Selvaraju K, Kumar S, Thota S. Cytomegalovirusinduced colonic stricture presenting as acute intestinal obstruction in an immunocompetent adult. BMJ Case Rep 2013; 2013:2013-200944. Doi: 10.1136/bcr-2013-200944

2 Nakase H, Herfarth H. Cytomegalovirus colitis, cytomegalovirus hepatitis and systemic cytomegalovirus infection: common features and differences. Inflamm Intest Dis 2016;1(01):15-23 